\author{
DAVID M.J. WOOD \\ INSTITUTO DE INVESTIGACIONES ESTÉTICAS, UNAM
}

\title{
Vestigios de historia: el archivo familiar en el cine documental y experimental contemporáneo
}

\begin{abstract}
Where once [history] was something one read about, one drew lessons from or tried to leave behind, inspected through stone monuments, written documents and other signs or traces, it now appears to exist in suspended animation, neither exactly "behind" us, nor part of our present, but shadowing us rather like a parallel world which is un-real, hyper-real and virtual, all at the same time. [...] History, it seems, has dropped out of sight and grasp between the news-flash of today and next month's mini-series.
\end{abstract}

ThOMAS ELSAESSER ${ }^{\mathrm{I}}$

$\mathrm{E}$ 1 (bi)centenario de la Independencia y de la Revolución mexicana, celebrado en 20Io, ocurrió en una doble encrucijada discursiva y tecnológica. Por un lado, el sentido aglutinador del nacionalismo posrevolucionario quedó para muchos en entredicho tras más de dos décadas de políticas neoliberales, un reacomodo de las estructuras partidistas tradicionales y la violencia generada por la guerra militarizada contra el narcotráfico a partir

I. Thomas Elsaesser, “'One Train May Be Hiding Another’: Private History, Memory and National Identity”, disponible en: http://tlweb.latrobe.edu.au/humanities/screeningthepast/ reruns/rro499/terr6b.htm (consultado el 5 de junio de 2013). Originalmente publicado en Society in Flanders and the Netherlands-A Yearbook, 1996-1997 (Rekkem: Flemish-Nederlands Foundation). 
de $2006 .^{2}$ Por otro lado, el creciente ímpetu de las tecnologías digitales estaba (y sigue) produciendo una transición radical en las formas de producir y de consumir los medios audiovisuales. El presente artículo propone un diálogo entre estas dos facetas de la nueva y emergente relación cine-nación, cristalizada en un cuestionamiento generalizado de la validez de un relato nacional narrado mediante la conmemoración de los grandes eventos apoteósicos.

\section{Desmontar monumentos}

La representación de los grandes acontecimientos nacionales ha sido una constante prácticamente a lo largo de la historia del cine mexicano. Sin embargo, podemos delinear un contraste, en términos muy generales y permitiendo excepciones, entre un impulso durante su auge industrial de los años cuarenta por monumentalizar el pasado nacional o convertirlo en folclor, y una tendencia en tiempos más recientes a presentar visiones más fragmentarias, parciales y a veces incluso deconstructivas de la historia. ${ }^{3}$ Por ejemplo, entre los realizadores comisionados para hacer películas de ficción por el Instituto Mexicano de Cinematografía (Imcine) con motivo del (bi)centenario en 2010, si bien algunos apostaron por recrear y analizar episodios históricos concretos, otros optaron por humanizar a las figuras de bronce de la historia patria. Para Claudia Arroyo, en estas películas predomina la sensación de que la Revolución es "un significante vacío", "algo hueco, una suerte de ausencia visualmente aludida en la pantalla o en stills y pósters". ${ }^{4}$ Algo parecido podría decirse del cine documental y experimental que se analizará en este artículo.

2. Gavin O’Toole, The Reinvention of Mexico (Liverpool University Press, 2010); Carlos Monsiváis, Apocalipstick (México: Debolsillo, 20I I).

3. Véase, por ejemplo, el análisis que hace Ignacio Corona de la cambiante imagen de Emiliano Zapata en varias etapas del cine de ficción mexicano; Ignacio Corona, "Emiliano Zapata y el fluctuante archivo de la imagen: del héroe trágico a la nostalgia neoliberal”, en La luz y la guerra: el cine de la Revolución mexicana, eds. Fernando Fabio Sánchez y Gerardo García Muñoz (México: Conaculta, 2010), 600-650; sobre la monumentalización nacionalista del metraje documental de la Revolución, véase David M.J. Wood, "Memorias de una mexicana: La Revolución como monumento fílmico", Secuencia, núm. 75 (septiembre-diciembre, 2009): I 47-I70.

4. "an empty signifier"; "something hollow, a kind of absence alluded to visually on screens or in stills and posters". Claudia Arroyo Quiroz, "Echoes of the Mexican Revolution: Cinema and Museographic Approaches to History in the 20I0 Bicentenary", Journal of Latin American Cultural Studies 20, núm. 4 (201 I): 377-395; las citas en 380 y 386. Según Arroyo 
Esta tendencia a desmontar la calidad monumental de la historia nacional en el cine contemporáneo ocurre en un momento tecnológico que ha producido una serie de transiciones en las formas de producir, de consumir y de percibir el cine. En años recientes, el espectáculo colectivo, envolvente y centrado de la sala cinematográfica tradicional se ha visto marginado, aunque no del todo desplazado, por la atomización, la fragmentación y la distracción que producen los mútiples formatos del consumo digital. En el plano ontológico, la indicialidad relativamente sólida del cine analógico, con su vínculo fotoquímico físico con una realidad profílmica, cede lugar a una codificación digital que tiene una relación indicial mucho más débil con una realidad tangible. 5 Sin pretender que haya una relación directa y causal entre la naturaleza de los cambiantes formatos cinematográficos y las estructuras políticas que habitan, no es descabellado sugerir que los dos ámbitos (el discursivo y el tecnológico) responden a una misma sensibilidad de época, o estructura de sentimiento: el cine de la modernización nacionalista absorbe; el cine de la fragmentación neoliberal individualiza.

Estos procesos están estrechamente vinculados con una creciente imbricación entre los discursos audiovisuales y la narración de la historia. La mediatización de los eventos históricos, y su conversión instantánea por el flujo mediático en objetos de consumo, ha dado lugar a otra transición en los propios términos del relato histórico per se. Según Thomas Elsaesser, la antigua función del cine, su función fundacional como registro de lo real, sufrió hacia finales del siglo xx la misma suerte que el propio concepto de la historia, esta última ya asociada con lo inauténtico, lo falso y lo falsificable. La historia monumental, y la capacidad del cine para documentarla, cedió frente a la nueva credibilidad de la memoria individual, la cual "ha adquirido estatura, como el repositorio de la experiencia genuina, el último refugio de lo que nos hace inalienablemente quienes somos". ${ }^{6}$ Es decir: sospechamos de la historia monumentalizada o

Quiroz, la película Revolución (2010) se plantea como un "antimonumento que buscaba escaparse de la lógica y retórica celebratorias del centenario" ("an anti-monument that sought to escape from the celebratory logic and rhetoric of the centenary", 386). Todas las traducciones al español son mías.

5. Henry Jenkins, "The Work of Theory in the Age of Digital Transformation", en A Companion to Film Theory, eds. Toby Miller y Robert Stam (Malden y Óxford: Blackwell, I999), 234-261.

6. "has gained in status, as the repository of genuine experience, the last refuge of what inalienably makes us who we are”. Elsaesser, “'One Train May Be Hiding Another”, s.n.p. 
mediatizada; confiamos casi instintivamente en las pequeñas historias individuales.

Los filmes que analizaré en este artículo se insertan en una corriente del cine documental y experimental reciente en México que plantea y debate una serie de inquietudes en torno a este paso del evento histórico monumentalizado a la fragmentación espacio-temporal de los discursos políticos y audiovisuales actuales. Si los nuevos paradigmas ofrecen formas más descentradas de narrar la historia, también provocan cierta ansiedad por la pérdida de los relatos redondos y coherentes de antaño.7 En sus diversos intentos de abrazar o de superar esa lejanía y fragmentación, estas películas recurren a lo que podríamos llamar el "archivo familiar".

Este término se refiere, por un lado, al denso tejido de recuerdos y narraciones subjetivos que los individuos que vivieron los eventos históricos articulan mediante las películas, o que sus familiares relatan de segunda (o tercera) mano, y que ofrecen narraciones paralelas sobre la historia. Por otro lado, también alude al rango de documentos (audio)visuales (fotografías, películas, grabaciones sonoras, etc.) preservados por los familiares, o bien descartados y rescatados por coleccionistas o por familiares, que agregan más capas de complejidad a tales relatos orales. A grandes rasgos, esta tendencia de volver a narrar el pasado colectivo mediante los pequeńos relatos de individuos que fueron atravesados por la historia, en vez de los grandes protagonistas, puede considerarse como cierta democratización de los términos de la representación audiovisual del pasado. Sin embargo, me propongo poner en tela de juicio la noción de que tales narraciones paralelas, o antinarrativas que desmontan la historia hegemónica, ofrecen una mayor autenticidad que los discursos monumentalizantes o falsificantes en el cine documental o de ficción.

\section{La historia recordada}

En la importante tradición del cine documental de compilación histórica sobre la Revolución mexicana, de las Historias completas de la Revolución que montó

7. Véase al respecto mi discusión del espectáculo multimedia de luz y sonido Yo México, celebrado en el Zócalo de la ciudad de México catorce noches consecutivas en noviembre de 20 io para conmemorar el centenario; David M.J. Wood, "Mexico: The Celluloid Revolution", Journal of Latin American Cultural Studies 20, núm. 4 (201 I): 449-46I. 
Salvador Toscano entre las décadas de I9I0 y I930, a las Epopeyas de la Revolución (Gustavo Carrero, 1963) que reúnen metraje filmado por Jesús H. Abitia, las imágenes en movimiento históricas tienden a servir como sustento visual de la instancia narrativa, expresada mediante intertítulos o una voz en off. En estos filmes predomina lo que Bill Nichols llama la "modalidad expositiva" del cine documental: la voz narrativa, racional y omnisciente provee la lógica organizativa de la película; las imágenes simplemente ilustran, iluminan o evocan las palabras de un narrador que va identificando lugares, fechas y acontecimientos clave del conflicto. ${ }^{8}$ La gran excepción, al menos en cuanto a la omnisciencia del narrador, es la compilación más conocida de todas: las Memorias de un mexicano (1950)9 de Carmen Toscano, hija de Salvador, que recurre a un narrador en primera persona, ficticio y subjetivo, quien relata sus propias vivencias de la Revolución, ante la incapacidad de la realizadora de garantizar con todo rigor que las imágenes efectivamente correspondían con los eventos que pretendían retratar. ${ }^{\mathrm{IO}}$ Memorias de un mexicano se caracteriza justamente por una fascinante tensión entre esta apelación a la memoria frente a su incapacidad para escribir Historia, y la calidad indudablemente patrimonial de una obra que el Instituto Nacional de Antropología e Historia declaró, en 1967, como "monumento histórico" de la nación. ${ }^{\text {II }}$ Aun así, Memorias no deja de utilizar extensamente la "edición evidencial" que, para Nichols, es clave en el documental expositivo: técnica de edición que no responde a criterios reflexivos, poéticos o estéticos, sino que sirve para mantener la continuidad y autoridad de la perspectiva del narrador.

Varios documentales independientes recientes van mucho más allá que Memorias de un mexicano en su recurso a la remembranza. En las Memorias de Toscano la voz subjetiva y particular sirve para suplir las carencias del discurso histórico, para no restar autoridad a la autenticidad histórica del metraje. La

8. Bill Nichols, Introduction to Documentary (Bloomington: Indiana University Press, 2010), I67-I7I.

9. Fragmento disponible en: http://www.veoh.com/watch/v206968294a3CRPxa?hI= Memorias+de+un+Mexicano (consultado el 2 de agosto de 2013).

ıo. Según la confesión de la propia dońa Carmen; véase David M.J. Wood, "Carmen Toscano", en Women Film Pioneers Project, eds. Jane Gaines y Radha Vatsal (Nueva York: Columbia University Libraries-Center for Digital Research and Scholarship, 2013), disponible en: https://wfpp.cdrs.columbia.edu/pioneer/ccp-carmen-toscano/ (consultado el 28 de febrero de 20I4).

I I. Véase Wood, "Memorias de una mexicana". 
tendencia actual va en el sentido contrario: se invoca la ostensible autenticidad del archivo familiar para superar lo simulada que resulta la historicidad del cine documental histórico.

Entre los filmes que recurren a esta estrategia están los documentales políticos Los últimos zapatistas (2002) y Francisco Villa, la Revolución no ha terminado (2006), ${ }^{12}$ ambos dirigidos por Francesco Taboada, que plantean rescatar una memoria popular de la Revolución mediante las remembranzas personales de veteranos sobrevivientes de la lucha armada y de sus familiares. Se trata de una serie de venerables ancianos cuyos microrrelatos de la Revolución presentan un claro desafío al relato oficialista de la Revolución institucionalizado por los regímenes posrevolucionarios. Pero también pretenden contrarrestar la fragmentación y la pérdida, en tiempos recientes, de los valores revolucionarios por los cuales ellos lucharon tantos años atrás.

Los documentales de Taboada evocan fotografías fijas y metraje documental ampliamente conocidos, que ya se han vuelto lugares comunes del recuerdo colectivo de eventos monumentalizados por la historia patria, tales como la entrada y la breve ocupación de la ciudad de México por las tropas de Villa y Zapata en 1914. Sin embargo, estas imágenes no se reciclan aquí por sus cualidades como evidencia, en la tradición posrevolucionaria de la Historia gráfica de la Revolución mexicana de Casasola ${ }^{13}$ o de los documentales de compilación de Salvador Toscano, sino que llegan a constituir elementos materiales de rituales colectivos o privados de remembranza personal. El registro fotográfico y fílmico se aleja de los circuitos del poder discursivo y mediático en los cuales originalmente fue producido y circulado, y se interpreta mediante voces y presencias que parecen ofrecer un vínculo más inmediato y real con el evento histórico (fig. I). Al mismo tiempo estos recuerdos, al ser documentados por la cámara de Taboada, se convierten en herramientas de la transformación política en el presente. ${ }^{I 4}$ Concretamente, los documentales de Taboada plantean que estos vestigios vivientes de la Revolución (fotográficos y humanos) pueden

I2. Disponibles en: http://www.youtube.com/watch?v=HnuaEawHijY; http://vimeo.com/ I3854873 (consultados el 2 de agosto de 2013).

13. Gustavo Casasola, Historia gráfica de la Revolución mexicana, I900-1960, 4 vols. (México: Trillas, I960).

I4. Véase Daniel Mosquera, "Close Up on the Mexican Revolution: Memory and Archive in Taboada Tabone's Documentary Films", Journal of Latin American Cultural Studies 20, núm. 4 (201 I): 397-4I8. 


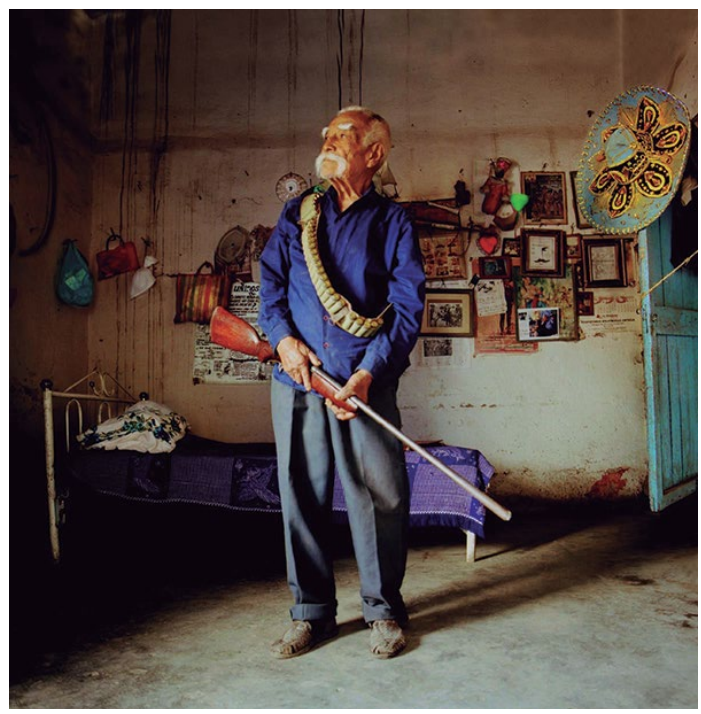

I. Still de Los últimos zapatistas (Francesco Taboada, México, 2002). Foto: Sarah Perrig. Cortesía de Francesco Taboada.

constituir un punto de partida para un levantamiento auténticamente contestatario en contra del orden neoliberal contemporáneo.

De una manera parecida, el documental El general (Natalia Almada, 2009) ${ }^{15}$ relee la historia patria por medio de una combinación de recuerdos personales y artefactos (audio)visuales, ejercicio que la película vincula con procesos políticos en el momento actual. A diferencia de los filmes de Taboada, que se enfocan en un grupo de personas de la gran masa anónima que vivió y sufrió la Revolución, El general se centra en una de las grandes figuras de la historia posrevolucionaria: el caudillo y presidente Plutarco Elías Calles. Mientras Taboada explora las posibilidades políticas de rescatar la memoria popular de los caudillos revolucionarios Zapata y Villa, Almada propone (y problematiza) una revisión de la figura menos venerada de Calles como posible redentor contemporáneo, pero desde una perspectiva íntima y familiar. El general revisa las

I5. Tráiler disponible en línea: http://www.youtube.com/watch?v=Mu-jlDPw3rQ (consultado el 2 de agosto de 2013). El general ganó el premio a la mejor dirección en documental en el festival de cine Sundance de 2009. 
percepciones tanto populares como académicas de Calles, así como una serie de registros fotográficos y fílmicos de su vida pública, por medio de la lente íntima de una colección de conversaciones grabadas en casete en junio de 1978 , entre Alicia Calles (referida en el filme como “Tita”), abuela de Almada e hija del general Calles, y su amigo el periodista Mauricio González de la Garza: parte de un proyecto inconcluso de ambos de escribir una nueva biografía del general. Tita, su voz interferida por el constante ruido de fondo de la reproducción de los casetes viejos, ofrece su propia versión fascinante de Calles, no como el Jefe Máximo consignado en la historia patria, sino como padre y hombre de familia, en un relato fragmentario, contradictorio y abiertamente parcial.

Tita, narradora distanciada, titubeante, ambigua, espontánea, tecnológicamente mediada, comparte la narración en off del filme con la voz más prosaica, monótona y ensayada de la propia Natalia, quien reflexiona desde el presente y en primera persona sobre las contradicciones entre Calles, el político maquiavélico, y Calles, el padre de familia, y sobre la imposibilidad de conocer el verdadero pasado de su bisabuelo. Cada voz invierte la función de la otra, y juntas delatan una serie de tensiones que permean toda la estructura de El general. La voz de Tita se presenta como uno entre varios sorportes visuales, auditivos y mnemónicos que construyen y a la vez interrumpen el relato histórico del documental; su ostensible indeterminación sirve para fracturar su interés declarado por reivindicar la memoria de su abuelo. En cambio la voz de Natalia, hablada desde el presente, es la presencia narrativa que organiza el sentido del documental: las frases que lee sobre la parcialidad del recuerdo y la imposibilidad de conocer el verdadero pasado rozan con una tendencia de racionalizar las múltiples capas del pasado que vemos y oímos según los criterios del presente. Así, en distintos niveles, las dos voces combinan elementos del documental expositivo que mencionamos líneas arriba, y del documental reflexivo que,

en vez de ver a través de los documentales hacia el mundo más allá, [...] nos pide que veamos el documental por lo que es: una construcción o una representación. [...] El acceso realista al mundo; la capacidad para proporcionar evidencia persuasiva; la posibilidad de la prueba incontestable; el vínculo solemne e indicial entre una imagen indicial y lo que representa -todas estas nociones se ven como sospechosas. ${ }^{16}$

I6. "instead of seeing through documentaries to the world beyond them, [...] ask[s] us to see documentary for what it is: a construct or representation. [...] Realist access to the world; the ability to provide persuasive evidence; the possibility of indisputable proof; the solemn, 
En este sentido, el filme pone en escena un dilema entre un deseo de cuestionar y de deconstruir las formas institucionalizadas y monumentalizadas de narrar la historia (concretamente, la historia de Calles), y un afán de construir un nuevo relato sobre el presente que se fundamente en parte sobre esa misma historia monumentalizada de la Revolución. Almada ha insistido en que el verdadero tema de El general no es la historia (porque ella no es historiadora) sino la naturaleza de la memoria en un nivel más abstracto: la mecánica del acto de recordar; el papel del cine en el acto de evocar el pasado. ${ }^{17}$ Pero hay cierta contradicción entre esta función filosófica en torno a la historia y la abierta agenda política del filme. Veamos cómo sucede.

Natalia Almada (en lo técnico, como directora; en lo formal, como narradora ${ }^{18}$ quiere entender y narrar a su bisabuelo, quien falleció unas tres décadas antes de que ella naciera. Naturalmente, ante la ausencia de recuerdos personales, no puede más que asir pedazos de memoria ajenos. A diferencia de la mayoría de nosotros, sin embargo, su almacén de memorias no constituye solamente los recuerdos de algún antepasado y alguna que otra fotografía, película casera u otra reliquia. Sus recuerdos íntimos y familiares, secundarios y heredados, se hallan envueltos en una maraña de referencias cinematográficas, artísticas, históricas y discursivas que constituyen fragmentos de la historia (audio)visual del siglo xx mexicano, historia que es propiedad común: noticieros viejos de grandes acontecimientos de la Revolución y tomas de posesión de presidentes; reportes e imágenes de prensa; fotografías de la vida pública; artes gráficas y visuales de la época posrevolucionaria; películas de ficción mexicanas y extranjeras sobre la Revolución (figs. 2 y 3). De este modo Natalia accede a la Revolución y a Calles mediante una "memoria prostética" cinematográfica: una forma de encontrarse con el pasado por medio de las "tecnologías de la memoria" mediáticas que posibilitan, por sus cualidades emotivas y empáticas, un acceso íntimo de parte del espectador a memorias de acontecimientos que

indexical bond between an indexical image and what it represents - all these notions come under suspicion”. Nichols, Introduction to Documentary, 194-197; énfasis original.

17. Almada cita a Marcel Proust y a Chris Marker como sus referentes teóricos más importantes; véase Cecilia Durán, "El general”, Perfil, suplemento de La Jornada Jalisco (I8 de marzo de 2009), 4. Este artículo, junto con otras críticas de El general, se pueden consultar en: http://www.altamurafilms.com/pressreviews.html (consultado el I de julio de 2013).

I8. De aquí en adelante me refiero a Natalia, la narradora de El general, y no a Natalia Almada la directora del documental, en un sentido biográfico. 


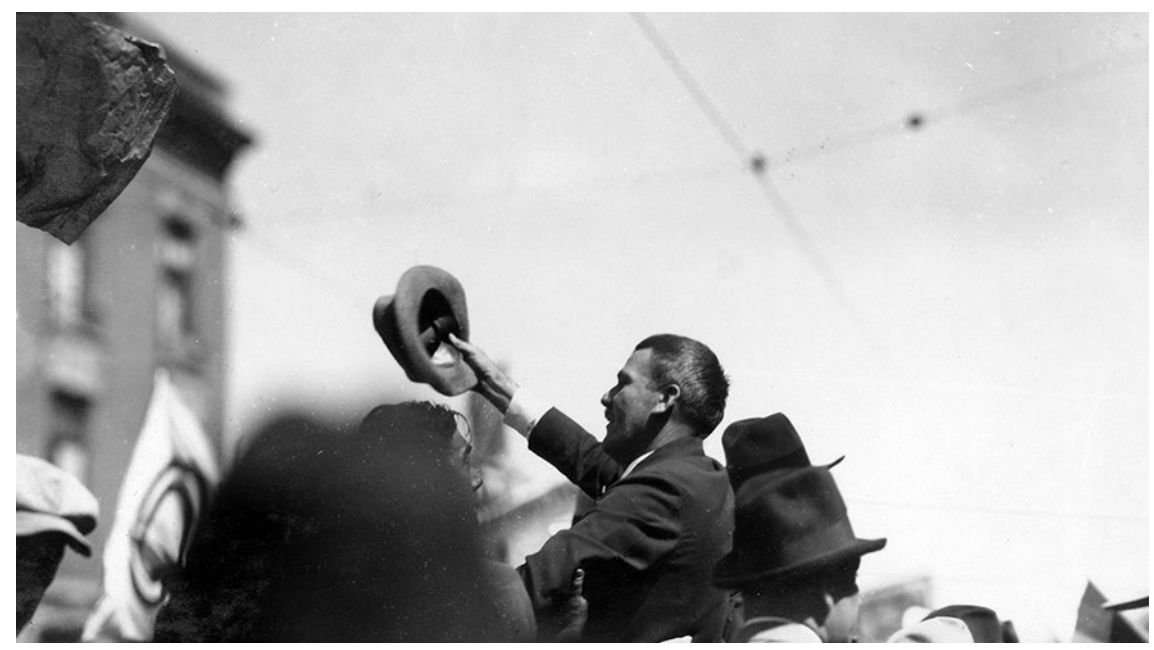

2. Fotograma de El general (Natalia Almada, México, 2009). Plutarco Elías Calles durante su campaña presidencial, I 924. Extraído de http://www.altamurafilms.com/photos/Calles_Presidente.jpg. Cortesía de Natalia Almada/Fideicomiso Archivos Plutarco Elías Calles y Fernando Torreblanca.

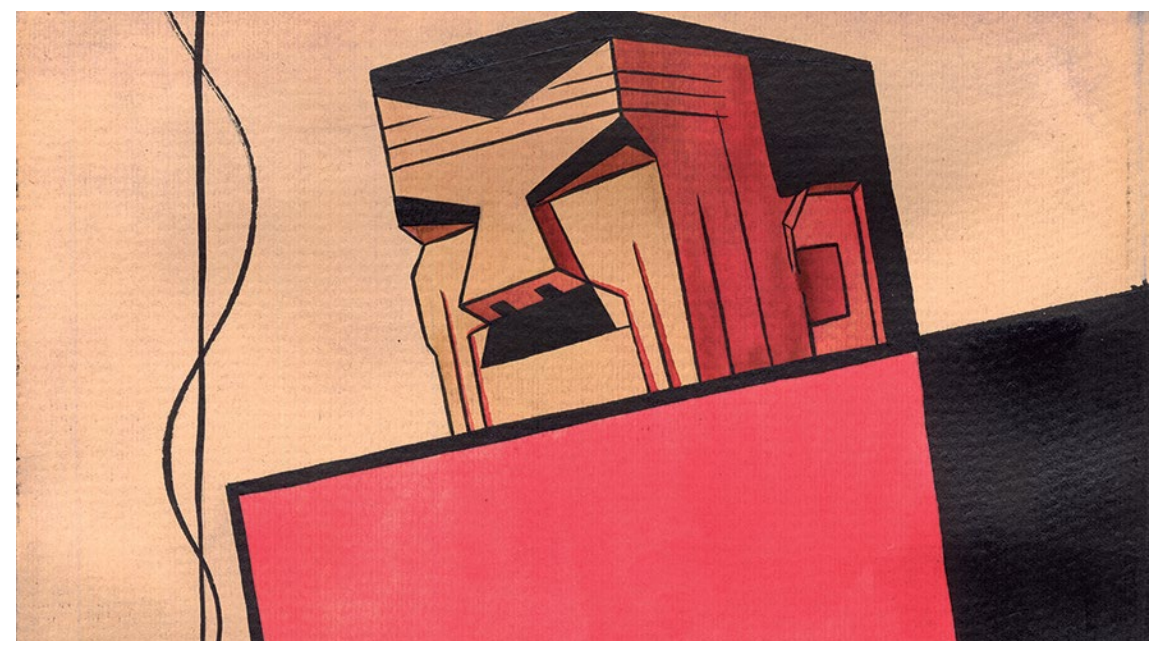

3. Fotograma de El general (Natalia Almada, México, 2009). Acuarela regalada a Plutarco Elías Calles en 1924. Extraído de http://www.altamurafilms.com/photos/Calles_acuarela.jpg. Cortesía de Natalia Almada/Fideicomiso Archivos Plutarco Elías Calles y Fernando Torreblanca. 
no vivió en carne propia. ${ }^{19}$ Las memorias prostéticas, observa Landsberg, no pertenecen exclusivamente a nadie, son propiedad común.

Landsberg ve las memorias prostéticas como una forma utópica y sensorial de posibilitar nuevas alianzas afectivas (por ejemplo interraciales o interétnicas) entre grupos de personas disparejas. Pero para Almada, la memoria prostética colectiva de Calles es una memoria institucionalizada, sesgada en contra de su antepasado. Su apuesta, entonces, es volver a adueñarse de la memoria de Calles. Esto lo hace releyendo y recontextualizando los artefactos (audio) visuales públicos que retratan a su bisabuelo y al entorno político posrevolucionario que vivió, y en buena medida moldeó, entretejiéndolos con una colección sorprendente e íntima de materiales fílmicos y auditivos que tratan de poner en jaque todo lo que creíamos saber sobre él.

Entre más indaga Almada en la figura de Calles, más se va dando cuenta de que lo que busca no es un personaje concreto históricamente comprobable, sino una serie de presencias e impresiones alojadas en imágenes, sonidos y recuerdos ajenos.

De cierto modo, el verdadero protagonista del documental no es Calles sino Alicia/Tita, el nexo de carne y hueso entre Natalia y don Plutarco, como lo atestigua una foto fija de Natalia como bebé en brazos de su abuela Alicia: "la foto con la que más he convivido a lo largo de los años". ${ }^{20}$ Por eso el filme no inicia con metraje histórico inmediatamente reconocible, sino con imágenes que el espectador promedio difícilmente puede descifrar: un viejo plano en blanco y negro de una joven elegante sobre un barco en el mar, que camina, sonriente y despreocupada, hacia la cámara (fig. 4). En un principio la toma, ligeramente desenfocada, parece natural; seguramente se trata de metraje familiar, filmado por su papá, su hermano, su esposo. Si nos fijamos bien, al continuar la toma la naturalidad de la joven parece convertirse en un performance de la naturalidad: se pone a contemplar el mar, buscando una pose espontánea; su mirada se vuelve hacia la cámara, y empieza a posar de manera autoconsciente. Momentos después vemos cómo la misma joven corre al agua y se sumerge en el mar; corte a un hombre en traje de baño que camina en silueta desde el mar hacia la cámara posada en la orilla. Su cara es irreconocible pero

19. Alison Landsberg, "Prosthetic Memory: the Ethics and Politics of Memory in an Age of Mass Culture", en Memory and Popular Film, ed. Paul Grainge (Mánchester y Nueva York: Manchester University Press, 2003), I44-I6I.

20. Natalia Almada, El general (México: Altamura Films, 2010), min. 34:40. 


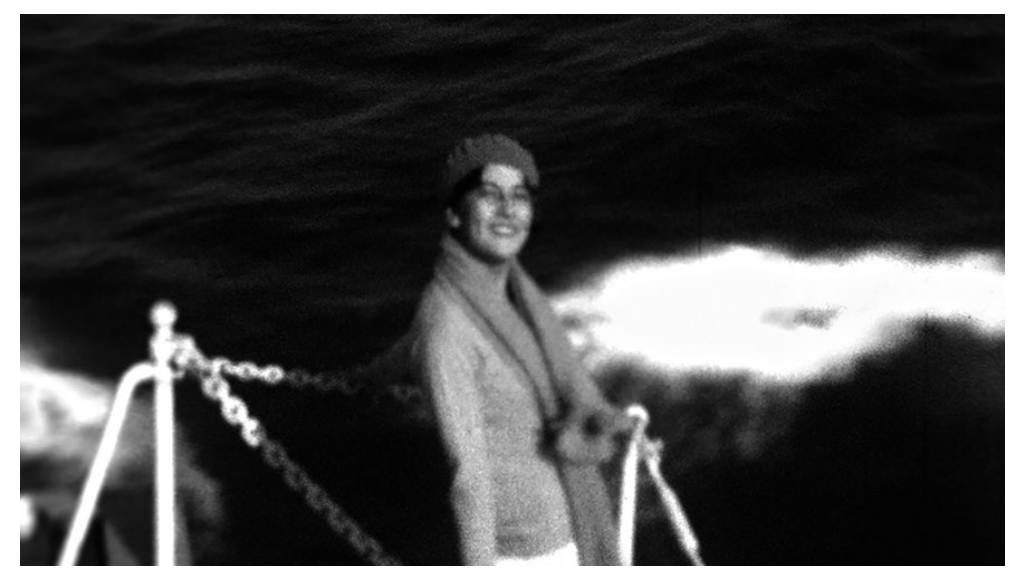

4. Fotograma de El general (Natalia Almada, México, 2009). Alicia Calles en su luna de miel en 1928. Extraído de http://www.altamurafilms.com/photos/El_ General_Tita.jpg. Cortesía de Natalia Almada/Fideicomiso Archivo Plutarco Elías Calles y Fernando Torreblanca.

dado el título del documental, la forma del cuerpo y su modo de andar, ¿podría ser el general Calles? Nada está claro, pero van apareciendo pistas (fig. 5).

Mientras tanto, este mismo juego entre lo espontáneo y lo actuado o repetido, lo conocible y lo inefable, también se va desplegando en la pista sonora. En el documental expositivo, podemos separar en todo momento el sonido diegético (el que pertenece al mundo de los sujetos o personajes) y el sonido extradiegético (el que sólo oímos los espectadores): queda claro qué pertenece al mundo representado, y qué pertenece a la narración. Pero desde los primeros momentos de El general tal separación se desdibuja: la música de la secuencia de créditos iniciales (compuesta por Shahzad Ismaily) se funde hábilmente con el sonido del botón de play de una grabadora. Por pocos segundos oímos, al lado del zumbido de la maquinaria del magnetoscopio deteriorado, algunas palabras de una mujer (es Tita, aunque todavía no lo sabemos), espontáneas pero incomprensibles, demasiado lejanas e indistintas como para ser oídas - seguramente no sabe que se está grabando. Unos momentos más tarde, mientras vemos una pantalla negra, escuchamos por fin las voces claras de la entrevista grabada, sobre un tictac de trasfondo (¡es el magnetoscopio deteriorado o la percusión de la música?), que parece delatar la identidad de la mujer, y también del hombre cuya silueta vamos viendo emerger desde el mar: 


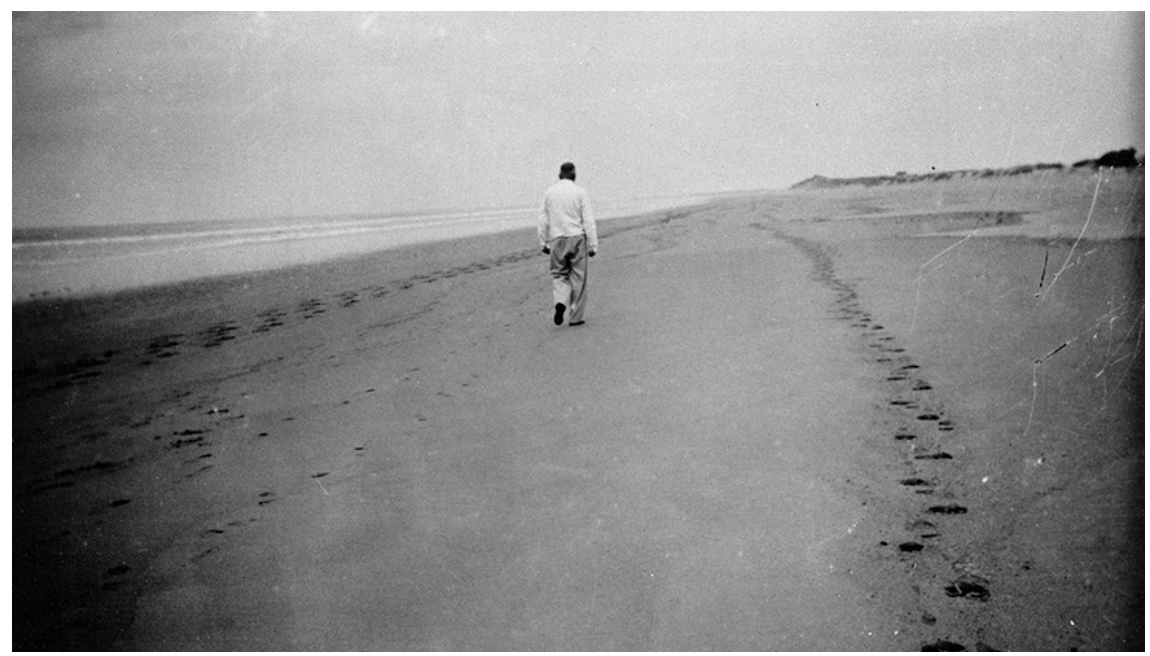

5. Fotograma de El general (Natalia Almada, México, 2009). Plutarco Elías Calles en la playa, Sinaloa, México, ca. I934. Extraído de http://www.altamurafilms.com/photos/Calles_beach.jpg. Cortesía de Natalia Almada/Fideicomiso Archivo Plutarco Elías Calles y Fernando Torreblanca.

Mauricio: ¿Cuál es tu primer recuerdo de tu papá?

Tita: Ah, eso es muy importante... Por ejemplo yo no tengo recuerdos así... pues recuerdo ciertas cosas pero más bien relacionadas conmigo misma, no con mi familia y no con mi padre.

En estos 80 segundos iniciales del documental, la alternancia entre la pantalla negra y el metraje de archivo en la imagen, y entre el play y el stop de la grabadora en el audio, desnaturalizan el discurso audiovisual: lo que vemos y oímos no es una narración lineal llana y lisa, sino una serie de fragmentos e interrupciones que se pueden iniciar, parar, repetir e intercalar. La aparente espontaneidad e invisibilidad de estos registros, evidentemente no profesionales, y la inmediatez con la cual nos ofrecen el acceso al pasado, están en cuestión. No podemos establecer una equivalencia temporal y espacial entre imagen y sonido; pronto se hará evidente que la voz grabada alude a un momento posterior al registrado en la imagen filmada, y no hay una relación causal entre ellos. Las voces grabadas proveen una narración en off, pero vienen de un tiempo que no es ni el de la filmación del metraje ni el de la realización del documental; es una narración que declara de entrada su propia incapacidad de recordar. Las múltiples posibilidades que se 
abren, sin embargo, se colapsan de repente cuando interviene la voz de Natalia, preocupada por dar datos referenciales. Revela que imagen y sonido remiten a dos tiempos distintos: la grabación en 1978 por Tita, hija de Calles, y otro momento años atrás (no sabemos exactamente cuándo) en la juventud de Tita. ${ }^{21}$

El afán de Alicia por reivindicar a su padre, y su incapacidad para arraigar su memoria de él en la certidumbre histórica que quisiera hallar, se convierten en la columna vertebral del documental. Por momentos, en las fotos fijas y el metraje de noticieros de la vida pública de Calles, la cámara inquieta de Almada se dilata en contemplar rastros de su vida privada contenidos en ellos: más notablemente, a niñas pequeñas que lo rodean (¿Alicia?, ¿alguna de sus hermanas?), cuyas miradas penetrantes o desinteresadas rebasan una simple interpretación convencional de Calles como el jefe máximo tiránico. Estas fotografías y películas, examinadas fuera del flujo mediático, parecerían darnos mucha información, pero cada fotograma sugiere tanto que jamás podremos saber. El filme busca lo particular o lo subjetivo en el seno de lo público, yuxtapone estas imágenes con home-movies de los Calles, o con fotografías de Alicia como una joven tratando de forjar su propio camino a la sombra de su padre. De este modo expresa la insistencia de la abuela en las lagunas de su propio conocimiento de su padre, pero también crea metáforas visuales del mismo proceso de grabar y de escribir sus recuerdos:

Tita: Es curioso cómo se te olvidan estas cosas, ¿̨no?...

Mauricio: Sí, necesitamos repasarlas y luego regresan...

T: Yo quiero poseer [?]...digamos, auténtica, ¿̨no? [...] Pero siento mi poca eficiencia para...para decirte lo que quiero decir. (pausa)

M: La palabra va acompañada de gestos, de sonrisas. Eso es lo que te falta, pero yo estoy aquí justamente para eso, Lucha, hay cosas que tú no estás diciendo pero que estás expresando. [...] Si es un libro que vamos a firmar los dos, tú dispones la mitad y yo pongo la otra mitad.

T: Tienes mucha razón: jsi no fuera por eso ni hubiera empezado! (33:I8)

Los coautores de la biografía de Calles ponen en evidencia la parcialidad del recuerdo, del proceso de externalizarlo y expresarlo en palabras, de su trans-

21. El home-movie de Alicia, comentado aquí, fue filmado durante su luna de miel en 1928; véase la página oficial de la película, http://www.altamurafilms.com/photos.html (consultada el 4 de junio de 20r3). 
cripción y de las posibilidades expresivas de la escritura. Mientras tanto la yuxtaposición de estas palabras con el metraje en blanco y negro pone en crisis cualquier arraigo semántico que éste pudiera tener en un pasado determinado.

En cambio, la narración contemporánea de Natalia y algunas de las estrategias de edición que la acompañan tienden a contradecir tal estética de la indeterminación. A pesar de su apelación a Chris Marker y a la complejidad con la que el cineasta francés analiza las marañas de registros y recuerdos que constituyen la memoria, Almada recurre con frecuencia a las fotos fijas y al metraje de archivo en capacidad de evidencia, o de reivindicación de un proceso político concreto actual. ${ }^{22}$ En varios momentos, El general acerca su propio proyecto callista al lopezobradorismo contemporáneo: el entonces candidato perredista llegaría a heredar y a redimir los valores auténticos de la Revolución (y, por extensión, de Calles) que el neoliberalismo desvió. Vuelco algo oportunista, quizá, de la cita de Marker que inspiró a Almada: "No recordamos; sólo reescribimos la memoria, igual que se reescribe la historia" (19:05). ${ }^{23}$

Como hemos visto, sin embargo, en sus momentos más punzantes El general demuestra cómo el pasado está hecho de capas mediatizadas que se intercalan y se contradicen, al entretejer, interrogar y apropiarse de testimonios visuales y auditivos provenientes de diversos tiempos y espacios. En Los últimos zapatistas y Pancho Villa: la Revolución no ha terminado, las voces de los informantes de Taboada ofrecen narraciones (más o menos parciales, más o menos confiables) sobre el pasado, hablados desde el presente. En El general, en cambio, coexisten y se solapan distintas esferas temporales: la vida pública y familiar de Calles en la época posrevolucionaria; momentos de la juventud de Tita; la Tita anciana que grabó sus recuerdos en 1978 ; el presente de Natalia Almada, quien recoge estos fragmentos del pasado en el contexto de las elecciones presidenciales de 2006; las diversas temporalidades cinematográficas que recogen los fragmentos de ;Que viva México! (Serguéi Eisenstein, I932), Vámonos con Pancho Villa (Fernando de Fuentes, I936) y Viva Zapata (Elia Kazan, 1952) que se encuentran diseminados por el documental. El protagonismo que adquieren en El general el metraje viejo, reciclado y reempleado, y las grabaciones en casete - las huellas visibles y audibles que dejan-, genera cierta reflexividad en torno al papel

22. Por ejemplo, al narrar la historia de Calles y Obregón mientras muestra fotos y metraje de ellos, 54:00; al ligar en plano-contraplano el viaje triunfal de Francisco I. Madero a la ciudad de México en I9I I con las protestas a favor del candidato presidencial Andrés Manuel López Obrador, con su lema revolucionario apropiado: "Sufragio efectivo, no reelección", i6:40.

23. La cita viene de Sans soleil (Chris Marker, Francia, 1982). 
de la tecnología en el proceso de la remembranza que rebasa una idealización de la autenticidad de los testimonios grabados y filmados.

El cine casero y el casete son sucesivas tecnologías que permiten a los individuos registrar y almacenar determinados momentos de sus vidas y pensamientos cotidianos, y son tecnologías que alteran radicalmente una concepción lineal del tiempo. Cuando Natalia acude a ellos en su intento de asir la figura de su abuelo, nos recuerda que su proyecto depende en gran medida de la "memoria mecánica": la memoria concebida no como la búsqueda del pasado narrativizada y articulada desde el presente, sino como objeto reproducible y repetible, una suerte de "memoria como sustancia" que nos permite "trasladarnos en el tiempo libremente, eligiendo los recuerdos a voluntad". ${ }^{24}$ Para Natalia, la narradora de El general, el significado del objeto rescatado (las grabaciones de audio, los fragmentos de películas caseras) no proviene de un intento romántico de rescatar su sentido perdido, sino que se produce a partir de un traslapo entre los significados que el objeto puede haber tenido en el pasado, y los que adquiere en el presente. De este modo el metraje de actualidades de la Revolución y de la posrevolución sale de nuestras manos: se desmonumentaliza, se vuelve un detonante de una nueva memoria prostética del general, construida alrededor de la subjetividad de Natalia. Si Elsaesser tiene razón al afirmar que la historia ha perdido su credibilidad ante el flujo de las memorias descentradas, el filme de Almada sería una operación de rescate simbólico de las imágenes de antaño.

24. "memory as substance"; "to move voluntarily across time, selecting memories at will". Jeffrey Skoller, Shadows, Specters, Shards: Making History in Avant-Garde Film (Mineápolis: University of Minnesota Press, 2005), 2-3. 


\section{La banalidad que estremece}

Cinema [...] seems to evoke the emotional certitude we associate with memory for, like memory, film is now, to a greater extent than ever before, associated with the body; it engages the viewer at the somatic level, immersing the spectator in experiences and impressions that, like memories, seem to be burned in.

ROBERT Burgoyne 25

De diferentes maneras los documentales de Taboada y de Almada releen desde abajo la historia monumentalizada de la Revolución y posrevolución. En última instancia, sugieren que las perspectivas alternativas ofrecidas por los diversos tipos de archivos familiares que movilizan nos llevan a una comprensión más perspicaz, o al menos más sentida, de los procesos históricos y políticos. Apelan a una tendencia contemporánea a desconfiar de la autenticidad del cine en tanto documentación o registro óptico del pasado, y a una creciente disposición a invertir en la atracción afectiva de las imágenes, sonidos y narraciones que remiten a vivencias e impresiones subjetivas. De este modo, están en sintonía con una corriente importante en la teoría contemporánea del cine que se centra no en la fidelidad positiva y comprobable del registro fílmico, sino en las verdades emotivas o embodied (encarnadas, corpóreas) que puede revelar; ${ }^{26}$ en el paso del "ocularcentrismo" del espectador racional y moderno a un interés por los impulsos sensuales y corpóreos que suscita el cine. ${ }^{27}$ Veamos esta tendencia teórica en el contexto más amplio de las prácticas actuales en la preservación y la realización cinematográficas.

En años recientes, los archivos fílmicos a nivel mundial han redoblado sus esfuerzos por rescatar, preservar y divulgar artefactos audiovisuales históricos, entre ellos el cine amateur y casero, que exceden y desafían los límites

25. Robert Burgoyne, "Memory, History and Digital Imagery in Contemporary Film", en Memory and Popular Film, ed. Paul Grainge (Mánchester y Nueva York: Manchester University Press, 2003), 223.

26. Robert Rosenstone, History on Film/Film on History (Nueva York: Pearson, 2012), 4445; Laurent Véray, Les images d'archives face à l'histoire. De la conservation à la creation (París: Scérén-CNDP-CRDP, 2OII): 243-244.

27. Thomas Elsaesser y Malte Hagener, "Cinema as Skin and Touch", en Film Theory: An Introduction Through the Senses (Londres y Nueva York: Routledge, 2010), I08-I28. 
de los cánones cinemáticos nacionales. El interés por parte de la comunidad archivística global en rescatar las llamadas "películas huérfanas" se remonta a los años noventa del siglo pasado. ${ }^{28}$ En México, los adelantos técnicos en la Filmoteca UNAM para preservar el cine en pequeños formatos característicos del cine casero, como el $9.5 \mathrm{~mm}$, y su iniciativa hace varios años "Saca tus películas del clóset", han sido fundamentales para el rescate y la difusión de materiales de origen no comercial. Más recientemente el proyecto Archivo Memoria, inaugurado en 20 Io bajo los auspicios de la Cineteca Nacional y ahora vinculado con el nuevo laboratorio de restauración digital de la Cineteca, se ha situado en la cresta de la ola. Archivo Memoria pide a individuos y a instituciones que donen (o entreguen en custodia) películas amateur y caseras a su acervo a cambio de una copia digitalizada del material y la preservación de los originales. ${ }^{29}$ También ha organizado dos muestras, en 201 I y 20I3, de material rescatado y de nuevas películas documentales y experimentales hechas a partir de los filmes amateur y caseros, que exploran la naturaleza, los significados, las implicaciones y los usos de este tipo de material. ${ }^{30} \mathrm{Si}$ bien el género del cine de reempleo (o de found footage) hecho a partir de películas de la "modalidad doméstica"3I

28. El propio término "películas huérfanas" - estrictamente, películas sin dueño ni derechohabiente activo, pero más ampliamente, cualquier filme que se salga de los circuitos comerciales, incluyendo películas industriales, educativas, noticieros, cine amateur, metraje de cámaras de circuito cerrado, entre otros - apela precisamente a la misma fuerza emocional y compasiva mencionada, como bien lo observó Paolo Cherchi Usai en su ponencia durante la primera edición del Orphan Film Symposium en 1999. Paolo Cherchi Usai, "What is an Orphan Film? Definition, Rationale and Controversy", ponencia en el simposio "Orphans of the Storm: Saving 'Orphan Films' in the Digital Age”, University of South Carolina, 23 de septiembre de 1999. Disponible en: http://www.sc.edu/filmsymposium/archive/ orphans20or/usai.html (consultada el 5 de julio de 2013).

29. Véase la página web del proyecto, http://www.cinetecanacional.net/bolcntk/?id=303 (consultada el 5 de julio de 20I3).

30. En la primera muestra, en 201 I, organizada en colaboración con el Orphan Film Symposium, predominó la difusión de películas huérfanas rescatadas, más de la mitad de las cuales provenían de archivos estadounidenses. En la segunda muestra en 2013, casi todo el material exhibido fueron películas mexicanas nuevas que se reapropian el cine casero o amateur. La creatividad artística que ha impulsado la preservación de las películas huérfanas en estos últimos años es patente.

3I. Tomo prestado el término de James M. Moran, quien propone que ni el cine casero ni el cine amateur pueden considerarse por sí mismos como "géneros" cinematográficos. Moran propone, de manera convincente, que hablemos de una home mode amplia (igual que el cine de ficción y documental son modalidades, y no géneros) que abarca una gran variedad de prácticas 
tiene una trayectoria de varias décadas en el nivel internacional, con realizadores de la talla de Péter Forgács, Alan Berliner y Jonas Mekas, en México pocos cineastas habían tenido la voluntad y las condiciones materiales para emprender tal proyecto antes del momento actual de la reproducción digital. Una excepción destacada es el largometraje documental La línea paterna (José Buil, 1995), hecho con metraje en 9.5 mm filmado por el abuelo del realizador, José Buil Belenguer, en los años veinte en Papantla, Veracruz. Ahora, sin embargo, parece ser un campo en crecimiento. ${ }^{32}$

Los estudiosos del tema lo han vinculado con el nuevo movimiento de la historia social que surgió en los años sesenta y setenta, cuando historiadores como E.P. Thompson y Eric Hobsbawm emprendieron la tarea de escribir la historia "desde abajo", y con los estudios del ámbito cotidiano por historiadores como Michel de Certeau que arrojaron contralecturas de la historia hegemónica. ${ }^{33}$ Para Patricia Zimmerman, el estudio de la modalidad doméstica de producción cinematográfica democratiza la historia del cine para abrirla a nuevos participantes no hegemónicos. Además ve en ella un caso particularmente llamativo de un cine que no constituye "evidencia documental inerte" de sucesos históricos, que no plasma una correspondencia directa entre hecho empírico y representación, sino que plantea una relación distinta con lo real: son imágenes que constituyen "construcciones móviles" (mobile constructs) las cuales entran en una relación dialógica con la historia. ${ }^{34}$ Tanto las propias películas no profesionales, como la creciente proliferación de tales materiales en y más allá de los

que se distinguen mediante varios vectores ideológicos y funcionales; James M. Moran, "Modes of Distinction: Home and Avant-Garde Modalities", disponible en: http://dspace.unav.es/ dspace/bitstream/I0I7I/I8513/I/Moran\%20-inglés\%2ofinal\%2opara\%2oweb.pdf (consultado el 4 de junio de 2013). Coincido con Moran, pero considero que es válido describir el cine que reemplea material de la home mode como un género del cine documental y experimental.

32. Uno de los pocos estudios académicos en abordar sistemáticamente un acervo de cine de aficionados en México es el de Magdalena Acosta Urquidi, "Harry Wright y el Cinema Club de México", de próxima publicación en las memorias del $6{ }^{\circ}$ Coloquio Nacional de Historia del Cine Regional (ed. Eduardo de la Vega). Agradezco a Magdalena Acosta haberme permitido leer este texto todavía inédito.

33. Patricia R. Zimmerman, "Introduction. The Home Movie Moment: Excavations, Artifacts, Minings", en Mining the Home Movie: Excavations in Histories and Memories, eds. Karen L. Ishizuka y Patricia R. Zimmerman (Berkeley y Los Ángeles: University of California Press, 2008), I-28; Efrén Cuevas Álvarez, "De vuelta a casa. Variaciones del documental realizado con cine doméstico", en La casa abierta. El cine doméstico y sus reciclajes contemporáneos, ed. Efrén Cuevas Álvarez (Madrid: Ocho y Medio, 2010), I2I-I66.

34. Zimmerman, "Introduction", 4-5, I6. Zimmerman sugiere entre líneas que el cine 
archivos fílmicos, sugieren, para Zimmerman, que "el archivo fílmico [...] es infinito. Está empezándose constantemente en vez de acabarse, abriéndose en vez de cerrarse". ${ }^{5}$ Aquí Zimmerman, al igual que otros historiadores y teóricos del cine amateur, casero o doméstico, se vale de la idea del "acontecimiento modernista" de Hayden White, en el cual la multiplicidad y la duplicidad de los registros mediáticos de los acontecimientos históricos contemporáneos provocan una "desorientación cognitiva" 36 que "revela las profundidades del acontecimiento histórico, demostrando cuántas capas de significado oculta". ${ }^{37}$

Las películas que discutí en el apartado anterior, que releen eventos clave de la historia mexicana (la Revolución, la consolidación posrevolucionaria del poder) por medio de archivos familiares, empiezan a abrir las puertas a este tipo de desorientación cognitiva al plantear todo un rango de nuevas versiones del pasado. Sin embargo, las estrategias narrativas tanto de Taboada como de Almada se apropian de tal desorientación para volverse, según Mosquera, "detonadores políticos latentes" ${ }^{38}$ Es decir, tienden a reorientarnos para vislumbrar nuevos capítulos en la historia de México: una nueva rebelión en contra del régimen neoliberal; la redención lopezobradorista de la Revolución. En este sentido sostienen la posibilidad de redimir el acontecimiento histórico por fines progresistas en el presente. En cambio los filmes caseros y amateurs, y las nuevas películas hechas con ellos, frecuentemente acaban del todo con la noción del acontecimiento histórico como principio organizativo de la historia: nos lanzan al océano del pasado sin arraigo. En el cine documental histórico, la Revolución, el maximato o el cardenismo serían hilos de la trama de la(s) historia(s) de México. En la modalidad doméstica, en cambio, esos hilos argumentales permanecen sólo como rastros o trasfondo, o desaparecen del todo. El pasado siempre está ahí, pero las pequeñas historias que ofrece aparecen no como sustento de un relato histórico, sino como capas casi aleatorias de

documental convencional sí constituye evidencia inerte con una correspondencia exacta entre hecho empírico y representación, postura que no me parece del todo justificable.

35. "the film archive [...] is infinite. It is constantly beginning rather than ending, opening up rather than closing". Patricia R. Zimmerman, "Morphing History into Histories. From Amateur Film to the Archive of the Future", en Mining the Home Movie, 275-288.

36. Hayden White, "The Modernist Event", en The Persistence of History: Cinema, Television, and the Modern Event, ed. Vivian Sobchack (Nueva York: Routledge, 1996), 17-38.

37. "it reveals the depths of the historical event, showing how many layers of meaning it conceals". Hayden White, “The Historical Event”, Differences: A Journal of Feminist Cultural Studies 19, núm. 2 (2008): 9-34.

38. "latent political detonators". Mosquera, "Close Up on the Mexican Revolution", 4I5. 
historia entre una cantidad insondable de acciones y presencias que constituyen la cotidianeidad del pasado. Se trata de una modalidad ritual, no representacional: lo que importa no es demostrar lo que pasó, sino sentir el latido de la vida cotidiana pasada, de la cual la propia película funge como sinécdoque. El sentido ritual de este cine, en primera instancia, depende en buena medida de la imbricación personal entre el espectador y las imágenes que él mismo filmó o protagonizó, o que lo remiten a momentos perdidos en el pasado de su propia familia. ${ }^{39}$ ¿Qué pueden decir tales imágenes, entonces, a un espectador que se encuentra enteramente fuera del círculo de producción y exhibición de la película doméstica?

Al ver la selección del II Encuentro Archivo Memoria en mayo de 2013, observé, a grandes rasgos, dos actitudes básicas hacia el metraje casero que reciclaron los cortometrajes y largometrajes contemporáneos incluidos en la muestra, y hacia la relación que entablan los filmes contemporáneos con los pasados aludidos por el metraje. Veo estas posturas como posiciones extremas que cualquier filme puede combinar y usar en mayor o menor medida. En la primera posición, una película sujeta el metraje viejo a un anclaje temporal, a una cronología lineal: la instancia narrativa, articulada desde el presente, observa, disfruta, ańora, o trata de restaurar el momento retratado. Se trata de una postura fundamentalmente nostálgica que busca significados firmes entre fragmentos de experiencias perdidas. La segunda postura implica un acercamiento más denso e inquisitivo a las temporalidades del metraje: reconoce que el acto de reciclarlo hace que las diversas temporalidades que invocan los registros (audio)visuales (su filmación, su abandono, su rescate, su reedición, su circulación y consumo) se vuelvan, en cierto sentido, coetáneos. Esta función dual del metraje familiar encontrado se perfila en los propios propósitos del proyecto Archivo Memoria, y también en el sitio web español www.yourlostmemories. com, del cual provienen varios de los trabajos incluidos en el Encuentro. El proyecto "Your Lost Memories" sirve como repositorio audiovisual que se esfuerza por reunir metraje encontrado con los que lo filmaron o protagonizaron; pero también constituye una semilla de la creatividad artística: su sección "Guest Cuts" invita a artistas contemporáneos a realizar nuevas películas a partir del mismo metraje. Apuesta por la restauración del sentido ritual del metraje, pero también por su fragmentación y repetición en un nuevo contexto artístico. Aquí el viejo metraje doméstico se lanza a una esfera pública cibernética para

39. Moran, "Modes of Distinction". 


\section{I 8}

DAVID M.J. WOOD

formar parte de nuevos debates y encuentros artísticos en torno al papel que tienen estos fragmentos del pasado en la comprensión del presente. $4^{\circ}$

En documentales como La línea paterna (José Buil, México, 1998), Papá Iván (María Inés Roqué, México/Argentina, 2000), ${ }^{4}$ Vuela angelito (Christiane Burkhard, México/Alemania, 200I ${ }^{42}$ o Carta a un ingeniero (Kyzza Terrazas, México, 20II), los realizadores/narradores tratan de restituir o de reconstruir el sentido perdido que yace en materiales y narraciones que aluden a sus propios pasados personales y familiares, y sus películas tienen en parte una función catártica. En Familia desconocida (Ezequiel Reyes, México, 2011) o Buscando a Larissa (Andrés Pardo, México, 20I I), ${ }^{43}$ los narradores/realizadores adquieren y escudrińan metraje casero ajeno, enigmático y anónimo, material trágicamente huérfano que tanto Reyes como Pardo tratan (con menor o mayor éxito, según el caso) de reunir con sus dueños originales para volverlo conocible, para completar el sentido originario que tenía el metraje en el ritual familiar, proceso en el cual el espectador se vuelve un foráneo cómplice (fig. 6). Una buena parte de la tensión y la seducción de estas cintas yace en el abismo temporal que todos sabemos que hay entre la filmación de los eventos que vemos en la pantalla y los distintos momentos de su reactivación en el presente (su hallazgo, su reedición, la experiencia individual de cada espectador). De lo que se trata es de reconciliar estos diversos momentos históricos para que las huellas audiovisuales se vuelvan legibles en el presente, para que podamos racionalizar el vínculo muy concreto con el pasado que proporciona el filme.

Otras películas, de corte más bien experimental, buscan nuevas modalidades expresivas que explotan las múltiples temporalidades que se hallan en el metraje, en vez de tratar de reconciliarlas. A priori/A posteriori (Alessandro Rivera, México, 20I2) ${ }^{44}$ utiliza una pantalla dividida en cuatro para presentar y repetir tanto simultánea como sucesivamente distintos momentos de un breve episodio de un niño jugando en la nieve afuera de su casa, (des)organizando lo

40. Sobre la llamada "democracia virtual" que conlleva la cultura cibernética y sus limitaciones, véase Adrian Athique, DigitalMedia and Society: An Introduction (Cambridge: Polity, 2013).

4I. Disponible en: http://www.youtube.com/watch?v=sa8bentv8du (consultado el 2 de agosto de 2013).

42. Fragmento disponible en: http://vimeo.com/44765280 (consultado el 2 de agosto de 2013).

43. Tráiler disponible en: http://www.youtube.com/watch?v=kbchfvwhQe4 (consultado el 2 de agosto de 2013).

44. Disponible en: http://vimeo.com/46552680 (consultado el 2 de agosto de 2013). 


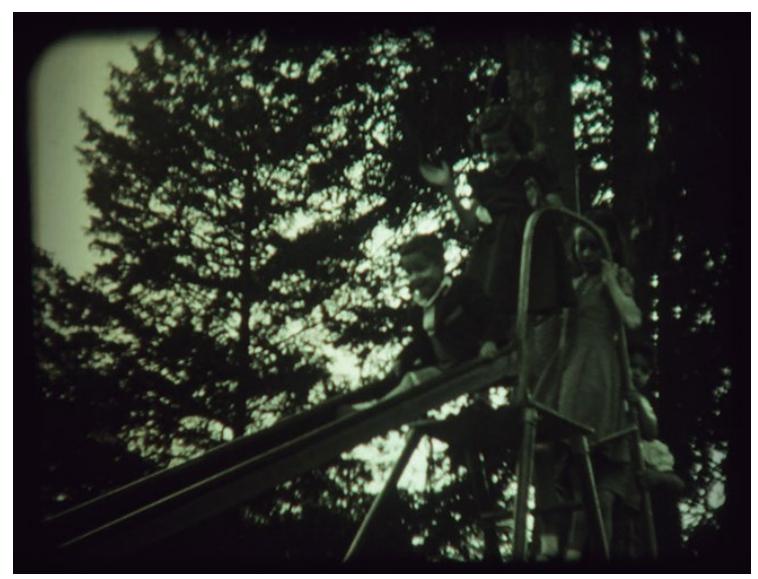

6. Fotograma de Familia desconocida (Ezequiel Reyes, México, 20 I I). Cortesía de Ezequiel Reyes.

que sería una narrativa extremadamente sencilla en una serie de reiteraciones aleatorias. De este modo, la pantalla partida se hace eco de y pone en evidencia la naturaleza del metraje como tiempo partido. ${ }^{45}$ El cortometraje Dramatis personae (Laboratorium, Espańa, 2005) ${ }^{46}$ y el largometraje La vida sin memoria parece dulce (Iván Ávila Dueñas, México, 2013) ${ }^{47}$ se alejan todavía más de un sentido original del metraje que reciclan, al forjar narrativas enteramente nuevas a partir de múltiples y diversas fuentes audiovisuales. ${ }^{48}$ Estos filmes realizan un "visionado desemantizado" (desemanticized seeing) 49 o una "lectura fuera del

45. El metraje, según los créditos finales del cortometraje, se filmó en marzo de 1970 y proviene de los archivos Prelinger en San Francisco, California.

46. Disponible en: http://vimeo.com/I8031037 (consultado el 2 de agosto de 2013).

47. Tráiler disponible en: http://www.youtube.com/watch?v=e5c6vviwr_o (consultado el 2 de agosto de 2013).

48. Encuentro que el cortometraje español lo logra con más éxito, ya que su historia, manejada con sutileza y abstracción y creada a partir de falsos raccords y otras técnicas visuales de montaje, parece emerger casi orgánicamente de los fragmentos audiovisuales que utiliza. El filme mexicano, en cambio, trata de forzar una narrativa hablada sobre imágenes que se resisten al sentido que se les trata de imponer. Éste, sin embargo, no es el lugar para entrar en críticas detalladas de las películas.

49. Wolfgang Ernst y Harun Farocki, "Towards an Archive for Visual Concepts”, en $H a$ run Farocki: Working on the Sightlines, ed. Thomas Elsaesser (Amsterdam University Press, 2004), 26I-286; esta cita en 272. 
encuadre" (de-framed reading) $)^{50}$ particularmente creativa de las imágenes en movimiento recicladas: un acto de la liberación de la imagen en movimiento de la temporalidad que su contexto sintáctico original le había adscrito; una activación de la posibilidad inherente del cine de repetir y de interrogar un momento filmado dado.

Esto se lleva a cabo por medio de una gran cantidad de estrategias visuales o sonoras: por ejemplo, mediante la manipulación física (alterando el color o la velocidad del metraje, o falsificando su proceso de descomposición), o con intervenciones contextuales o narrativas (técnicas de montaje, uso de pantalla dividida, intervenciones sonoras), para cuestionar la historicidad del metraje y arrancarle su calidad de registro del pasado. No obstante, incluso en estos experimentos extremadamente "desemantizados", el vínculo indicial entre el metraje y lo registrado no desaparece del todo: permanece en tanto residuo o huella de lo real..$^{5 \mathrm{E}} \mathrm{El}$ arte, y el potencial crítico del metraje, reside en las formas que encuentra el cineasta de activar sentidos paralelos y transversales del metraje sin perder de vista su vínculo con una realidad tangible original. Por eso la potencia de muchos de estos filmes surge de su capacidad para entretejer aspectos de las dos posturas que delineé arriba: por un lado, la seducción del índice del pasado, y por otro, su deconstrucción.

Gregorio Rocha está entre los artistas mediáticos mexicanos con más habilidad para explotar las posibilidades expresivas y analíticas de esta tensión entre el deseo del espectador de acercarse a un pasado redondo y cerrado, y la emoción de descubrir cómo los diversos pasados encerrados en metraje viejo y rescatado se abren en sentidos múltiples e inesperados. Su proyecto reciente Amateurs es el resultado de un trabajo de ańos de coleccionar metraje no profesional vintage que arroja luces nuevas e inciertas sobre los momentos y acontecimientos históricos. En un episodio particularmente inquietante del

50. Roger Odin, "Reflections on the Family Home Movie as Document: A Semio-Pragmatic Approach", en Mining the Home Movie: Excavations in Histories and Memories, eds. Karen L. Ishizuka y Patricia R. Zimmerman (Berkeley y Los Ángeles: University of California Press, 2008), 255-27I.

5I. Malin Wahlberg concibe algo similar en el cine de Chris Marker, referente clave (hasta diría en boga) entre los reempleadores contemporáneos del metraje encontrado: la huella audiovisual constituye tanto una "marca estática" (static mark) de una realidad determinada, como una "transición temporal" (temporal transition) que ocupa el intervalo entre la filmación y el escrutinio posterior de la imagen. Malin Wahlberg, Documentary Time: Film and Phenomenology (Mineápolis y Londres: University of Minnesota Press, 2008), I02. 
proyecto (titulado "Sincronía”), Rocha yuxtapone con una pantalla dividida metraje amateur filmado por dos camarógrafos distintos simultáneamente, en la misma demostración militar en el puerto de Veracruz en 1929: Jesús M. Aguirre, gobernador militar de Veracruz bajo Plutarco Elías Calles, y José María Labarga, agente aduanal y empresario español residente en Veracruz en ese momento. A primera vista los breves fragmentos de habilidad ecuestre podrían parecer bastante banales, pero su potencia viene de la forma en la que Rocha enmarca los clips. Antes de correrlos, un título inicial nos informa que poco después de este suceso, "Aguirre sería apresado y fusilado por el gobierno de P. Elías Calles". Al ver este metraje, no puedo evitar examinarlo una y otra vez, buscando alguna pista que me diga por qué Aguirre resultó inconveniente para el régimen: ¿podemos detectar, acaso, alguna mirada subversiva en su forma de encuadrar la demostración...? Por supuesto, mis propósitos se vieron frustrados.

De este modo, las imágenes adquieren la misma gravitas estremecedora que una fotografía fija de una persona que, sabemos, está a punto de morir: el registro fotográfico como el tiempo embalsamado, en los términos de Bazin. ${ }^{52}$ Las imágenes se vuelven interesantes no por la información visual que ofrecen ni las realidades que imitan, sino por lo que no muestran: la violencia política que está tan cercana a este metraje, pero que está tan patentemente ausente. El metraje no nos cautiva por su capacidad evidencial y ocular (mira, esa demostración militar ocurrió entonces, y la podemos ver), sino en tanto huella de un acontecimiento que no podemos ver ni conocer, pero que de alguna forma sí podemos intuir (imagínate, algo transcendental ocurrió, después y cerca de esta imagen tan banal). Activamos, pues, un "visionado desemantizado", pero sin soltar del todo un deseo (inalcanzable) de habitar la temporalidad original del metraje. No nos dice gran cosa sobre la posrevolución o el maximato (no nos sorprende que un gobernador de la época haya sido asesinado), sino que nos asalta en un nivel corpóreo, nos estremece.

52. "Esas sombras grises o de color sepia, fantasmagóricas, casi ilegibles, no son ya los tradicionales retratos de familia, sino la presencia turbadora de vidas detenidas en su duración, liberadas de su destino [...] porque la fotografía no crea — como el arte— la eternidad, sino que embalsama el tiempo; se limita a sustraerlo a su propia corrupción”. André Bazin, "Ontología de la imagen fotográfica”, en ¿Qué es el cine? (Madrid: Ediciones Rialp, 2012), 23-30; esta cita en 29. 


\section{Un duelo interrumpido}

Terminaré por considerar brevemente la siguiente pregunta: si el gran interés actual por la modalidad doméstica de parte de los archivos fílmicos y de los realizadores del cine documental y experimental nos pone en contacto cada vez más con formas de la imagen en movimiento que son más descentradas, más privadas, más corpóreas, más dispersas, más parciales, más fragmentarias que las formas tradicionales, ¿qué dimensiones críticas y políticas podría tener este cine?

No hay consenso al respecto entre los estudiosos. Para Zimmerman el cine amateur en su primera época, antes de la primera guerra mundial, tenía una fuerza subversiva particular al hacer intervenciones tajantes en la vida pública, a diferencia de la forma más ideológicamente conservadora y domesticada del cine propiamente casero que llegó a predominar en la posguerra. ${ }^{53}$ Para Moran ésta es una postura errónea que proviene de la falsa premisa de que cualquier uso no profesional de los medios audiovisuales debería ser contestatario, exigencia que el cine casero difícilmente podría sostener. Moran sugiere más bien que tanto el cine amateur como el casero tienen sendos aspectos conservadores y radicales que son propios de la naturaleza peculiar de cada forma. ${ }^{54}$ Odin, por su parte, expresa una profunda sospecha ante las películas caseras y familiares: son formas de ver sesgadas y altamente selectivas; su aparente inocencia y su poder de seducir y de emocionar les permite eludir la "cuestión de la verdad" (truth question) con la cual automáticamente desafiamos el cine documental. Más aún, para Odin el interés actual por ellas es sintomático de un creciente individualismo, una disolución de los espacios públicos estructurados, un proceso reaccionario de encubrir los conflictos sociopolíticos con el afecto.55 Parece lógico, pues, que Antonio Weinrichter concluya que al documentalista que recicla y compila tal material "lo que le guía no es tanto la denuncia o el afán de explorar la inscripción de trazas ideológicas como la recuperación de una memoria desvanecida; y la interrogación que se hace de las imágenes apropiadas es menos política que poética". ${ }^{66}$

Hay formas, sin embargo, de encontrar en la poética de estos registros escurridizos una fuerte carga crítica. La cómoda dualidad entre intervenir el

53. Zimmerman, "Morphing History into Histories".

54. Moran, "Modes of Distinction".

55. Odin, "Reflections on the Family Home Movie", 267.

56. Antonio Weinrichter, Metraje encontrado: la apropiación en el cine documental y experimental (Pamplona: Gobierno de Navarra/Institución Príncipe de Viana, 2009), 96. 


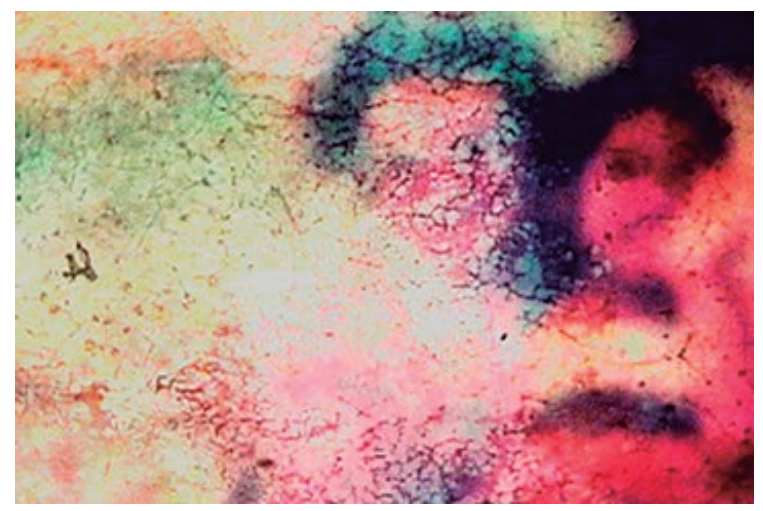

7. Fotograma de Estela (Bruno Varela, México, 2012). Cortesía de Bruno Varela.

material casero o amateur y reunirlo con su dueńo original adquiere otro matiz en el último cortometraje que voy a comentar: Estela (Bruno Varela, México, 20I2). ${ }^{57}$ En común con otros trabajos audiovisuales de Varela, Estela se constituye a partir de fragmentos aparentemente inconexos de películas ajenas y extrańas ("retazos de imagen y sonido", dicen los créditos finales), filmadas, en este caso, en cine súper 8 , video 8 , vHS y DVD: indígenas celebrando una fiesta; un rodeo; escenas de reuniones y vacaciones familiares; gente trabajando en un campo; una niña indígena que va de la mano de su mamá (fig. 7). Ésta, como otras películas experimentales de Varela, explora, en sus propias palabras, el "carácter fantasmagórico y doble" del metraje viejo, "registro íntimo e inacabado", "hemorragia de recuerdos ajenos", "memoria en estado primigenio y latente", "contenido abierto, en fuga". 58 A grandes rasgos la obra de este artista puede concebirse como una crítica a los regímenes del conocimiento y de la representabilidad en corrientes más convencionales de la antropología visual: ámbito en el cual él mismo se formó. Esta crítica es particularmente oportuna en Estela, ya que la antropología visual comparte con la modalidad doméstica una fuerte inversión en el valor íntimo y ritual de sus registros: una estrecha cercanía entre la filmación y los usos de la imagen en movimiento.

57. Disponible en: http://vimeo.com/51365254 (consultado el 2 de agosto de 2013).

58. Bruno Varela, "La(s) otra(s) vida(s) de las imágenes", en Habitar: cuaderno de trabajo, Simposio Injerto 20Io, ed. Eduardo Thomas (México: Ambulante/Fundación Jumex, 2010), 86-93. 
A diferencia de otras películas, sin embargo, en Estela la abrupta separación entre el tiempo presente de las propias imágenes en movimiento y el acto ya pasado de filmarlas o de coleccionarlas — la ruptura de la referencialidad o de la función ritual de las imágenes — no es meramente circunstancial. Las imágenes de Estela, según los créditos finales del propio filme, se encontraron en una caja perteneciente a una mujer que vivía en un pueblo de la sierra Mixe de Oaxaca. De acuerdo con la narración en off del señor Hermes Rojas, en lengua mixe, se trata de una forastera que llegó a su pueblo, quizá una guerrillera queriendo esconderse, que se quedó mucho tiempo como maestra y un día desapareció, dejando solamente unas cuantas pertenencias personales, entre ellas los registros audiovisuales que vemos aquí. Más tarde llegó la noticia de que murió. Según relata (en zapoteco) otro oriundo del pueblo al final del corto, "ya no hay buen maíz desde que se fue, ya no hay buena milpa porque no encontramos los restos [de su cuerpo]". 59 La imposibilidad de hallar los sentidos de este metraje extraviado se vuelve metáfora del desasosiego del pueblo, su duelo interferido por la incertidumbre de la desaparición. El filme, más aún, es un documento tramposo. Varela relata que si bien la historia es real, la protagonista es ficticia; el testimonio en mixe es una reconstrucción de un relato originalmente en español; el testimonio en zapoteco en realidad viene de otro pueblo y contexto (se refiere a la desaparición de un ídolo, o estela). El metraje que vemos tiene diversos orígenes: mercados de pulgas, la colección de Varela, otros proyectos. ${ }^{60}$ Los dejos de autenticidad del documento audiovisual son un espejismo.

El propio título de la pieza cristaliza esta suspensión del sentido. Estela es el nombre de la protagonista ausente (y ficticia) de esta pieza; pero también, como señalan las definiciones de diccionario que aparecen en los textos iniciales ("Estela: rastro que deja en el aire un cuerpo luminoso en movimiento") y finales ("Huella o recuerdo que deja cualquier cosa que pasa"), sugiere un índice fugaz, una ausencia tangible. Si las imágenes y los sonidos de esta colección, apariciones y reiteraciones de ultratumba, son pedazos de "memoria como sustancia" (en palabras de Skoller), son sustancias sin arraigo ni hogar. En un vuelco diestro en los últimos segundos del filme después de los créditos finales, y después de la imagen final de una lápida, se nos recuerda el otro significado de la palabra "estela": "Monumento conmemorativo que se erige sobre el suelo en forma de pedestal o lápida". La estela monumental y lapidaria, que tiende

59. Estela (Bruno Varela, México, 20 I 2).

6o. Comunicación personal con Bruno Varela, 2 de agosto de 2013. 
a cerrar y fijar significados, no se opone a la estela fugaz que tiende a eludirlos, sino que se reconcilia con ella. Debajo de los monumentos siempre hay incertidumbres, pero por otro lado, no podemos sino buscar formas de arraigar los sentidos sueltos. De este modo la película, al reciclar sus imágenes y sonidos, realiza una suerte de duelo postizo por Estela.

En el contexto del México actual, afligido por la violencia, las desapariciones y los desplazamientos forzados, y por la apuesta generalizada de sus medios audiovisuales por sensacionalizar esta situación en vez de analizarla, este poner en evidencia el desarraigo del registro audiovisual constituye sin duda un acto sumamente político. Estela desmonta pero también energiza la añoranza por la solidez perdida que provocan las películas analógicas en tiempos digitales, los relatos familiares o comunitarios en tiempos violentos, y los relatos nacionales en tiempos neoliberales. Revela la fugacidad del sentido que subyace a los monumentos malogrados que se erigen para consolidar afiliaciones identitarias: la otra resonancia del título del filme es con la sonada, costosa y controvertida Estela de Luz, monumento construido en el Paseo de la Reforma e inaugurado por el gobierno federal en 2012 (el mismo ańo que el filme de Varela) con motivo del Bicentenario. Pero también convoca a la erección de nuevos "monumentos" audiovisuales resbaladizos que ayuden a confrontar (si no a comprender) este escenario.

Si Odin se preocupa por el debilitamiento de la esfera pública que está asociado con el giro hacia la modalidad doméstica del cine, Estela propone una forma sutil y sin esencialismos de criticar y pensar esta pérdida de lo público, esta imposibilidad mediática contemporánea de racionalizar la historia y de ofrecer narrativas alternativas. El filme no puede ni intenta escaparse de la lógica de la dispersión y del fragmento, pero ni celebra ni trata de amainar la distancia entre registro y evento. Más bien, nos la demuestra en toda su crudeza y desafía las implicaciones de nuestra incomprensión. Si el archivo fílmico, siguiendo a Zimmerman, está abriéndose perpetuamente en vez de cerrarse, este hecho por sí solo no necesariamente democratiza el acceso a la historia audiovisual; el vínculo directo que parece ofrecer con el pasado a veces es tramposo. Los vestigios de historia que expone y nos hace sentir no son mero folclor, sino materiales de construcción. \$

N. B. Presenté una versión preliminar y parcial de este artículo en el XXXI Congreso Internacional de la Latin American Studies Association, Washington, D.C., en mayo-junio de 2013 . 